\title{
Board Profile and its Influence on the Stock Value of Oil Companies and Gas
}

\author{
Sávio de Luna Pinto ${ }^{1}$, Aline Alves de Andrade ${ }^{1}$, Roselaine Cristina Borges ${ }^{1}$, Celso Machado Jr. ${ }^{1}$ \\ ${ }^{1}$ School of Management, Centro Universitário das Faculdades Metropolitanas Unidas, São Paulo, Brazil \\ Correspondence: Sávio de Luna Pinto, Centro Universitário das Faculdades Metropolitanas Unidas, São Paulo, Brazil, \\ Av. Liberdade 749 - $7^{\circ}$ andar CEP: 01503-001, São Paulo, Brazil. Tel: 3209-4589. E-mail: savio.luna.pinto@ gmail.com
}

Received: May 11, 2016

Accepted: May 27, $2016 \quad$ Online Published: June 12, 2016

doi:10.5539/ibr.v9n8p37

URL: http://dx.doi.org/10.5539/ibr.v9n8p37

\begin{abstract}
This article identifies the profile of the boards of the ten largest companies in the Oil and Gas industry on NASDAQ and the variation of their stocks. The research contributes to the study developed by Andrade (2009) which established the relationship between corporate governance and market value in Brazil. Additionally, Connell and Cramer (2010) studied the advice of Ireland companies, point out the importance of analyzing the board's composition and its influence on the organization's performance in the stock market in different segments. The method was a qualitative analysis of the board, and the correlation of the board with the variation and point that studies in a number of other countries generally fail to report any significant association between board composition and firm performance. The research information shows that the best performing companies have common characteristics: advice with fewer members; age diversity of members and specifically trained in master. These characteristics capable of being incorporated by the companies and that give power to favorable conditions for companies, for shareholders and for society in general.
\end{abstract}

Keywords: corporate governance, stock exchange, board members

\section{Introduction}

Corporate governance is an important tool for companies to clearly show their performance to the market (OECD, 2015). Disclosure of performance indicators, is positioned as one way to show that performance, enabling the reduction of information asymmetry between managers and shareholders (Pereira et al., 2010). The identification and control of indicators, to be disclosed, is one of the board's responsibilities due to the need for shareholders to have means to analyze the company's performance (Schwartz-Ziv; Weisbach, 2012). In this context, the profile of board members is an item of attention to analyze in order to identify their influence on the behavior of the company's stocks.

The oil and gas sector is an important activity that involves various types of transactions. In Brazil the oil and gas sector accounts for $13 \%$ of Gross Domestic Product GDP (PETROBRAS, 2016) and its influence is significant. With greater or lesser participation, it is possible to infer that this activity has significant impact on the economy of many countries. Despite the importance of the oil and gas segment to countries this activity is performed by companies. It is noteworthy that there are cases where governments exert much influence on the control of companies in the segment, but even in this case the end result of the activity is linked to the performance of companies.

This context provides the purpose of this research, that is to identify whether the profile of the board interferes with the performance of ten Oil and Gas company stocks listed on NASDAQ. The analysis covers the period from January 2010 to September 2015.

Besides this introduction, this study presents a theoretical framework, the methodology used, the presentation and analysis of data with the discussion and closing remarks.

\section{Theoretical Frame of Reference}

According to Ribeiro (2007), the capital structure of American business is divided so that even the controller does not have a significant portion of stocks. Ribeiro (2007) sets out the need for a professional board to manage the company and reduce conflict problems. With this context, many American companies are managed by professional managers, not by their owners, or group of shareholders.

Facing non-participation of the owners in daily activities and decisions of organizations, the shareholders have their interests represented in the companies through the board. Among the existing studies on the board, a study by Martins 
and Rodrigues (2005) stands out, they theorized on the strategic role of the board, and its impact on corporate governance. Despite the importance of the board to shareholders, it is positioned as a cost that reduces the yield of stocks. In this theme, studies of Linck, Netter and Yang (2008) examined the cost and benefit of management and supervision activities developed by the board.

The activities of management and supervisory board are part of the impact that a board has on a business. Regarding these impacts, Baptista (2012) approach the difficulty of studies due to intrinsic reasons of confidentiality of business and the methodological validity of the techniques undertaken to survey data.

The existence of the board to monitor the interests of shareholders in the company's management process stands as a cornerstone of Corporate Governance. However, to Gomes et al. (2006) the simple implementation of a Board does not guarantee the adoption and best practices of Corporate Governance. To the author, the Board shall have characteristics that enable a satisfactory performance in defense of the company's performance.

Silveira et al. (2003) reported that several studies seek to associate the Board composition with the performance of companies, most often questioning whether the composition of the board members by external, non-executive, improve the company's performance. Baysinger and Butler (1985) reported, through research, that there is no significant relationship between the accounting measures of performance and the proportion of outside directors on the board. In contrast, however, Baghat and Black (1999) argue that there exists a significant relationship between board composition and corporate performance when comparing companies with Board formed mostly of independent members and companies with Board without this majority.

Corroborating the above, Andrade, et al. (2009) concluded in his work that the board composition of non-executive members, can be a good mechanism to improve the performance index, except for companies that have high levels of debt. The authors expose further that internal advisors can redirect the company's results in pursuit of raising the operating profit level, being knowledgeable of business processes. In this sense Arosa et al. (2013) confirm the position of Andrade, et al. (2009) to propose that the presence of external advisers can improve the company's performance.

Previous research such as Rosenstein and Wyatt (1990) find a positive relationship between financial returns and companies with indication of external directors (not members of the board). This context expands the analysis of the proposed Weisbach (1988) who claimed to find a negative association between poor performance and change of chief executive for boards of companies formed in the majority of external directors. For this author the performance is more associated to those responsible for management than for the members of the board. However, it is noteworthy that for Fama and Jensen (1983), Jensen and Meckling (1976) and Shleifer and Vishny (1997) the centralization of authority may result in the domination of the board of management and negatively impact performance.

Guerra (2010) explores the roles of the Board and its relevance in the corporate governance system, notes that the size and age of the company, is not decisive for the quality of governance of the Board. However, Gomes et al. (2006, p. 1) states that "the adoption of a Board reveals to the market that the company cares about good corporate governance practices and the very transparency, demonstrating responsibility for their results," making clear importance of the Board for the satisfactory performance of the company.

The results presented in the study by Gomes et al. (2006, p. 10) shows:

(...) the companies surveyed consider the board member as a professional with great respect, integrity and commitment, and with relevant knowledge about the market and the company, and can contribute significantly to the company's growth.

Silveira, et al. (2003, p. 61) found that:

(...) almost no relationship between board composition (INDEP) and value converges with the results described in the study of Hermalin and Weisbach (1991, p. 3), which state that one of the main results of the empirical literature on boards is the absence of correlation between board composition and corporate performance variables.

According to Pace et al. (2003, p. 41) in his study of the performance indicators as drivers and value:

Non-traditional measurements, valuing the independent board, the most democratic forms of control of the company, the continuity of management, as well as their experience and ethical behavior are in line with recent measures aimed at corporate governance, confirming understanding its ability to influence the behavior of managers, the future results and attitude of investors.

In contrast, Andrade, et al. (2009, p. 28) reported that monitoring of the managerial decisions of external directors "(...) can cause the opposite effect to the performance when added to a possible pressure from creditors that aim to cash flows through interest on loans ". 
Andrade et al. (2009) mentions also that the responsibilities assumed by the Board can contribute significantly to explain the performance and market value of companies. Still on this subject, the authors conclude that "the stock market tends to value the company's stocks with a board composed of a greater number of directors", and positive relationship between the number of directors and the operating margin (Andrade et al., 2009, p. 27). Additionally, Andrade, et al. (2009, p. 29) ascertains:

(...) that companies with similar profile compositions on the board provide different impacts on their market value, as the size of the company, or on their performance, as the debt ratio.

As for the impact of the diversity of the Board on the company's performance, we can mention Fraga and Silva (2012, p. 73), they concluded through their research that "there is a relationship between the diversity of educational aspects of the board members and market performance of the company, although in different directions (that is; positive for years of education and negative for courses related to teaching). " The authors emphasize, too, that the presence of women on the board is very small, but companies that have at least one woman on board had better market performance than those who had no female member.

Fraga and Silva (2012) argue that the greater the diversity of the board, the better the performance. However, Ararat, Aksu and Cetin (2010) in a similar survey found no evidence that diversity in board composition in relation to 'sex, age and education' influence the economic performance of companies.

Contributing to the relevance of the above considerations, Raheja (2005) argues the importance of insiders for the company due to the availability of information to the board. He also claims that their experience can improve performance but can distort the objectives.

\section{Method}

This is a qualitative research supported by documentary analysis. We conducted a descriptive analysis of the boards of the ten largest companies in the oil and Gas sector listed on NASDAQ (it is an automated stock market in the United States which lists more than 2,800 different company's stocks). This research uses the information provided in the NASDAQ web pages that has the respect of investors of each of these companies. Access was held on November 15, 2015. On that date the ten largest companies in the oil and gas sector were: Exxon Mobil (XOM), Chevron (CVX), Petro China (PTR), BP p.l.c. (BP), Total Final Elf (TOT), Schlumberger N.V. (SLB), China Petroleum \& Chemical Corporation (SNP), Conoco Phillips (COP), ENI S.p.A. (E), Occidental Petroleum Corporation (OXY).

The information listed that have been identified and used in this research were: - sex, - age, - number of board members, - type of board members, - the undergraduate level and - earlier experiences of the board members. These data relating to members of the board.

Further, using the same web page data collection was done for a descriptive historical analysis of stocks in the period from January 2010 to October 2015 for the 10 companies under investigation. The analysis sought to identify positive, negative and neutral variations (or patterns).

The analysis is based on two aims - to identify behaviors that relate and impact of the profiles of the boards on the variations in the stocks of companies. It is noteworthy that the stocks were classified as "devaluation of stocks" (less than 5\%), "appreciation of stocks" (above 5\%) and "standard range" (between 5\% and -5\%).

The analysis of the board's profile and performance was carried out from the correlation method between each of the variables found in the profile of boards and performance variables. The interpretation of the analysis was performed by Shimakura (2006) in "Relationship Coefficient Interpretation".

The model indicates a correlation between the upper variable to zero is positive, while a lower correlation than zero is negative. Moreover, the approach of positive and negative values to a (positive or negative) indicates the degree of correlation: very weak, weak, moderate, strong, very strong. Table 1 depicts the model used.

Table 1. Interpretation of Relationship Coefficient

\begin{tabular}{cc}
\hline Value of p $(+$ or -$)$ & Interpretation \\
\hline 0.0 a 0.19 & A very weak correlation \\
0.20 a 0.39 & A weak correlation \\
0.40 a 0.69 & A moderate correlation \\
0.70 a 0.89 & A strong correlation \\
0.90 a 1.00 & A very strong correlation \\
\hline
\end{tabular}

Source: Shimakura, S. E. 2006. Interpretation of Relationship Coefficient. Avaliable at <http://leg.ufpr.br/ silvia/CE003/node74.html>. Accessed on March 2015

The following Chapter presents the data identified in the survey. 


\section{Results and Discussion}

After the identification of data, it was possible to classify the companies' boards in gender, size, age, affiliation with the company, the undergraduate level, previous experience in other companies or government. Table 2 shows the board's composition by gender of its members. The companies are presented in the tables according to their position in the ranking of the top ten, so BP is the largest oil and gas company in the world and XOM is the tenth largest company in the sector.

Table 2. Board composition by gender

\begin{tabular}{lcccc}
\hline Company & Country & Male & Female & Total Number \\
\hline BP & United Kingdom & $80 \%$ & $20 \%$ & 15 \\
COP & USA & $82 \%$ & $18 \%$ & 11 \\
CVX & USA & $83 \%$ & $17 \%$ & 12 \\
E & Italy & $67 \%$ & $33 \%$ & 9 \\
OXY & USA & $80 \%$ & $20 \%$ & 10 \\
PTR & China & $100 \%$ & $0 \%$ & 11 \\
SLB & USA & $70 \%$ & $30 \%$ & 10 \\
SNP & China & $100 \%$ & $0 \%$ & 11 \\
TOT & France & $67 \%$ & $33 \%$ & 12 \\
XOM & USA & $83 \%$ & $17 \%$ & 113 \\
Total & & $81 \%$ & $19 \%$ & \\
\hline
\end{tabular}

Source: Research Data

The data in Table 2 show that of all board only 19\% are women. It is worth noting that Chinese Oil and Gas companies show up 100\% male, while the European women's composition is already almost one third of the board. Another average was the composition of $20 \%$ female for English-speaking regions women are dominant on their boards. The average number of board members of composition is 11 per company, this item does not identify a differentiated profile for country. The Table 3 shows the board's composition according to the age of its members.

Table 3. Composition of Board by age of board members

\begin{tabular}{ccccccccccc}
\hline & $\begin{array}{c}\text { United } \\
\text { Kingdom }\end{array}$ & USA & USA & Italy & USA & China & USA & China & France & USA \\
\hline Age & BP & COP & CVX & E & OXY & PTR & SLB & SNP & TOT & XOM \\
Up to 50 years & $0 \%$ & $9 \%$ & $0 \%$ & $44 \%$ & $0 \%$ & $9 \%$ & $10 \%$ & $9 \%$ & $8 \%$ & $0 \%$ \\
$\mathbf{5 1}$ to 60 years & $47 \%$ & $27 \%$ & $42 \%$ & $44 \%$ & $10 \%$ & $73 \%$ & $40 \%$ & $64 \%$ & $33 \%$ & $17 \%$ \\
61 to 70 years & $53 \%$ & $64 \%$ & $50 \%$ & $11 \%$ & $80 \%$ & $9 \%$ & $50 \%$ & $27 \%$ & $58 \%$ & $83 \%$ \\
$>70$ years & $0 \%$ & $0 \%$ & $8 \%$ & $0 \%$ & $10 \%$ & $9 \%$ & $0 \%$ & $0 \%$ & $0 \%$ & $0 \%$ \\
\hline
\end{tabular}

Source: Research Data

The data in Table 3 indicates that the consolidated average age composition is concentrated between 61 to 70 years. The company Eni S.p.A. (E) shows different behavior with $44 \%$ of the composition of the board members under the age of 50 years. Only two American companies and a Chinese company's board members are over the age of 70 years.

Table 4 shows the board members (excluding Presidents and CEOs) differentiating them from internal and external.

Table 4. Composition of companies by the Board characteristics

\begin{tabular}{lccc}
\hline Company & Country & External Directors & Internal Directors \\
\hline BP & United Kingdom & $80 \%$ & $13 \%$ \\
COP & USA & $91 \%$ & $0 \%$ \\
CVX & USA & $92 \%$ & $0 \%$ \\
E & Italy & $78 \%$ & $0 \%$ \\
OXY & USA & $90 \%$ & $0 \%$ \\
PTR & China & $36 \%$ & $45 \%$ \\
SLB & USA & $90 \%$ & $0 \%$ \\
SNP & China & $36 \%$ & $45 \%$ \\
TOT & France & $67 \%$ & $17 \%$ \\
XOM & USA & $92 \%$ & $0 \%$ \\
\hline
\end{tabular}

Source: Research Data

In Table 4 you can see that Chinese companies are those with largest number of internal directors, with $45 \%$ of the total. As a counterpoint American companies do not have internal board members. Table 5 shows the level of education of Board members. 
Table 5. Composition of the Board for Graduate Level

\begin{tabular}{ccccccccccc}
\hline & $\begin{array}{c}\text { United } \\
\text { Kingdom }\end{array}$ & USA & USA & Italy & USA & China & USA & China & France & USA \\
\hline Company & BP & COP & CVX & E & OXY & PTR & SLB & SNP & TOT & XOM \\
\hline $\begin{array}{c}\text { Doctorate } \\
\text { degree }\end{array}$ & $13 \%$ & $9 \%$ & $17 \%$ & $0 \%$ & $10 \%$ & $45 \%$ & $0 \%$ & $73 \%$ & $0 \%$ & $17 \%$ \\
$\begin{array}{c}\text { MBA } \\
\text { Master's } \\
\text { degree }\end{array}$ & $0 \%$ & $0 \%$ & $0 \%$ & $0 \%$ & $0 \%$ & $0 \%$ & $0 \%$ & $0 \%$ & $17 \%$ & $0 \%$ \\
NA & $7 \%$ & $0 \%$ & $8 \%$ & $22 \%$ & $10 \%$ & $36 \%$ & $0 \%$ & $18 \%$ & $0 \%$ & $0 \%$ \\
\hline
\end{tabular}

Source: Research Data

Table 5 shows that in analyzing the composition of boards, Chinese companies favors board members with a doctorate or master's degree, while US companies do not identify as relevant these criteria when choosing their board members, since they have $25 \%$ or less board members with some graduate.

Table 6 presents the experience of the members of the boards of the companies surveyed.

Table 6. Professional experience of Board Members

\begin{tabular}{lccll}
\hline Company & Country & Experience as CEO & Experience as a Director & Experience in Government \\
\hline BP & United Kingdom & $67 \%$ & $100 \%$ & $27 \%$ \\
COP & USA & $64 \%$ & $82 \%$ & $36 \%$ \\
CVX & USA & $75 \%$ & $100 \%$ & $42 \%$ \\
E & Italy & $67 \%$ & $78 \%$ & $67 \%$ \\
OXY & USA & $70 \%$ & $100 \%$ & $50 \%$ \\
PTR & China & $82 \%$ & $64 \%$ & $9 \%$ \\
SLB & USA & $60 \%$ & $100 \%$ & $20 \%$ \\
SNP & China & $82 \%$ & $82 \%$ & $36 \%$ \\
TOT & France & $58 \%$ & $83 \%$ & $42 \%$ \\
XOM & USA & $83 \%$ & $92 \%$ & $8 \%$ \\
\hline
\end{tabular}

Source: Research Data

Table 6 indicates that over $60 \%$ of the board has previous experience as president of the company - CEO and $80 \%$ as a director in other companies. One criterion that has enough variation and precludes a framework is the existence of previous experience in government activities. The American company Exxon Mobil (XOM) has 8\% of its directors with previous experience in government while the Italian company Eni S.p.A. (E) has $67 \%$ of its directors.

Table 7 shows the historical values of the closing stock for each of the companies in the period January 2010 to October 2015. This table indicates how many percentages in the action depreciated (down more than 5\%), valued (growth of more than $5 \%$ ) or maintained a default value (between $5 \%$ positive $5 \%$ negative).

Table 7. Stocks Variation

\begin{tabular}{lcccc}
\hline Company & Country & Devaluation of Stocks & Appreciation of Stocks & Standard Variation \\
\hline BP & United Kingdom & $23 \%$ & $24 \%$ & $53 \%$ \\
COP & USA & $54 \%$ & $27 \%$ & $19 \%$ \\
CVX & USA & $41 \%$ & $31 \%$ & $28 \%$ \\
E & Italy & $28 \%$ & $36 \%$ & $36 \%$ \\
OXY & USA & $31 \%$ & $43 \%$ & $26 \%$ \\
PTR & China & $29 \%$ & $38 \%$ & $33 \%$ \\
SLB & USA & $36 \%$ & $29 \%$ & $35 \%$ \\
SNP & China & $44 \%$ & $27 \%$ & $29 \%$ \\
TOT & France & $41 \%$ & $25 \%$ & $34 \%$ \\
XOM & USA & $37 \%$ & $22 \%$ & $40 \%$ \\
\hline
\end{tabular}

Source: Research Data

The data in Table 7 shows that the American company Conoco Phillips (COP) suffered higher devaluation of stocks to the average $54 \%$ of the analyzed period, while Occidentum Petroleum Corporation (OXY) got appreciation of stocks greater than the average 43\% of the analyzed period. That is, between 2010-2015 the company Conoco Phillips (COP) suffered devaluation of its stocks in more than half of the period while Occidentum Petroleum Corporation (OXY) won appreciation almost half of the period.

Table 8 shows the correlation of gender (men and women) with the number of members of the Board and the related change in the value of stocks. 
Table 8. Correlation of Men and Women and the size of the Board vs. Variation in Stocks

\begin{tabular}{lccc}
\hline & Correlation Men & Correlation Women & Correlation Size \\
\hline Devaluation p & 0.11 & -0.11 & -0.16 \\
Valuation p & 0.09 & -0.09 & -0.61 \\
Standard p & -0.18 & 0.18 & 0.60 \\
\hline
\end{tabular}

Source: Research Data

The results show very weak correlation to the presence of men and women on the board, so the gender of board members of companies do not interfere with the performance of companies. The data in Table 8 makes it possible to identify a moderate positive correlation between standard variation of the stocks and board size, so companies with directors with the most members had higher support the value of their stocks (standard range). However, the largest number of members on the board also resulted in moderate negative correlation with the valuation.

Thus, Table 8 showed that the gender variable of the board members did not exercise influence on the performance of company stock. The result of no influence of gender on the performance of stocks of oil and gas companies of this research is in contrast to those reported by Fraga and Silva (2012) that points to the importance of women on the board.

Regarding the board size, the results were different to those found by Andrade et al. (2009) which states that there is a positive relationship between size and value of the stocks by the market. For the survey conducted in the oil and gas industry, the results were moderately negative for the valuation of stocks.

Table 9 shows the correlation of age of the members of the board and its change in value of the Stocks.

Table 9. Age Correlation vs. Variation in Stocks

\begin{tabular}{lcccc}
\hline & $\begin{array}{c}\text { Correlation } \\
\text { <50 years }\end{array}$ & $\begin{array}{c}\text { Correlation 51 to } \\
\text { 60 years }\end{array}$ & $\begin{array}{c}\text { Correlation 61 to } \\
\mathbf{7 0} \text { years }\end{array}$ & $\begin{array}{c}\text { Correlation > } \\
\mathbf{7 0} \text { years }\end{array}$ \\
\hline Devaluation of Stocks & -0.16 & -0.18 & 0.26 & -0.23 \\
Appreciation of Stocks & 0.27 & 0.04 & -0.30 & 0.77 \\
Standard Variation & -0.03 & 0.17 & -0.06 & -0.33 \\
\hline
\end{tabular}

Source: Information presented in the relationship with the investor page

The data in Table 9 shows that the presence of a member with more than 70 years on the board pointed to the appreciation of the company stock, therefore, the correlation between age test of board members and change in stocks showed a strong positive correlation between the age of 70 years and appreciation of stocks, this is the most important result of this test. However, it is worth noting that only one of the surveyed companies presented director in this condition. These results are contrary to research Ararat Aksu and Cetin (2010) that found no correlation between age and performance.

Table 10 relates the fact that the director be internal or external and the corresponding change in the value of the Stocks.

Table 10. Correlation between Types of Directors vs. Variation in Stocks

\begin{tabular}{lccc}
\hline & Devaluation of Stocks & Appreciation of Stocks & Standard Variation \\
\hline External Director & 0.08 & -0.11 & -0.00 \\
Internal Director & -0.06 & 0.03 & 0.04 \\
\hline
\end{tabular}

Source: Information presented in the relationship with the investor pages

Analysis of internal or external director's variable in Table 10 shows a very weak correlation at all points analyzed (depreciation, valuation and standard). Surveys conducted on the subject differ on the subject. While Baysinger and Butler (1985) portray the absence of correlation between performance and external members on the board, Andrade et al. (2009) and Arosa et al. (2013) showed a positive correlation in their findings, stating that external members positively influence the valuation of company stock.

Table 11 shows the influence of the undergraduate level in the valuation of companies.

Table 11. Correlation between undergraduate level x Variation in Stocks

\begin{tabular}{lcccc}
\hline & $\begin{array}{l}\text { Doctorate } \\
\text { Degree }\end{array}$ & MBA & $\begin{array}{l}\text { Master's } \\
\text { degree }\end{array}$ & NA \\
\hline Devaluation of Stocks & 0.13 & 0.18 & -0.43 & 0.05 \\
Appreciation of Stocks & 0.01 & -0.27 & 0.60 & -0.20 \\
Standard Variation & -0.13 & 0.03 & -0.01 & 0.10 \\
\hline
\end{tabular}

Source: Information presented in the relationship with the investor pages

The most significant results of the correlation shown in Table 11, between the director at the graduate level and the variation of the actions were a positive moderate correlation between board members with master and appreciation of stocks; moderate negative correlation between master and devaluation of stocks; weak negative correlation between 
recovery actions and MBA; and weak negative correlation between recovery actions and graduation Unknown (NA). In this condition the education at Master's degree level appeared favorable for the valuation of the company.

Table 12 shows the influence of professional experience of the director in the valuation of companies.

Table 12. Correlation between Work Experience $\mathrm{x}$ Variation in Stocks

\begin{tabular}{lccc}
\hline & Experience as CEO & Experience as a board & Experience in Government \\
\hline Devaluation of Stocks & -0.08 & -0.08 & 0.02 \\
Appreciation of Stocks & 0.08 & -0.19 & 0.38 \\
Standard Variation & -0.00 & 0.22 & -0.29 \\
\hline
\end{tabular}

Source: Information presented in the relationship with the investor pages

Regarding significant results for professional experience, presented in Table 12, it was found that a weak positive correlation between members with previous experience in government and appreciation of stocks and a weak negative correlation between standard variation and experience in Government.

Following this study highlights the main points noted in the survey.

\section{Closing Remarks and Acknowledgments}

After the realized correlation test, we are able to identify important relationships between performance and board profile. Some of the characteristics of the board showed no significant correlation with the stock performance of companies. However, it was possible to find relevant characteristics for the formation of the board of oil and gas companies. The main characteristics found for the formation of a good performance with the board of directors are: moderate negative correlation for board size and appreciation of the stocks; moderate positive correlation between maintenance of actions (standard range) and board size - these conditions of board with fewer members perform better, but the board with more show less variation both positive and negative; strong positive correlation between the presence of member with age over 70 years and appreciation of stocks - companies with directors with over 70 years showed good recovery of their actions; and moderate positive correlation between Master's degree holders and appreciation of stocks - the presence of members with Master's degree was beneficial for the valuation of companies.

Objectively the research information show that the best performing companies have common characteristics: advice with fewer members; age diversity of members and specifically trained in master. These characteristics capable of being incorporated by the companies and that give power to favorable conditions for companies, for shareholders and for society in general.

For the survey it is important to note that different countries have different characteristics to the creation the boards, which can generate different results if the research is developed in a single country. This is evident when observing the difference between American companies, with the presence of $100 \%$ of the directors as external members; and European and Asian companies with greater mix of external and internal members. Another limitation of the research is the lack of information on former members of the board which could enable better understanding of the trajectory of the company board of directors. Note that the profile of the company's board is only one of the variables that interfere with the performance of their stocks. Other global profile variables that impact on all companies, or local variables that affect the performance of only a few companies influence the valuation of companies.

The development of similar researches performed, but focusing on other segments of the economy presents opportunity to identify the influence of the board in the general business.

\section{References}

Andrade, L. P., Salazar, G. T., Calegário, C. L. L., \& Silva, S. S. (2009). Governança Corporativa: uma análise da relação do conselho de administração com o valor de mercado e desempenho das empresas brasileiras. Revista de Administração Mackenzie, 10(4), 4-31.

Ararat, M., Aksu, M., \& Cetin, A. T. (2010). Impact of board diversity on boards' monitoring intensity and firm performance: evidence from the Istanbul stock exchange. Social Science Research Network, working papers series, 2010. Retrieved on Nov. 18, 2015 from: http://ssrn.com/abstract=1572283

Arosa, B., Iturralde, T., \& Maseda, A. (2013). The board structure and firm performance in SMEs: Evidence from Spain. Investigaciones Europeas de Dirección y Economía de la Empresa, 19(3), 127-135. http://dx.doi.org/10.1016/j.iedee.2012.12.003

Baptista, M. A., \& Soares, M. (2012). Conselhos de administração e monitoração da implementação estratégica: um modelo conceitual. Economia Global e Gestão, 17, (special edition), 55-75.

Baysinger, B., \& Butler, H. (1985). Corporate governance and the board of directors: performance effects of changes in 
board composition. Journal of Law, Economics and Organization, 1(1), 101-124.

Bhagat, S., \& Black, B. (1999). The uncertain relationship between board composition and firm performance. Business Lawyer, 54, 921-963.

Connell, V., \& Cramer, N. (2010). The relationship between firm performance and board characteristics in Ireland. European Management Journal, 28, 387-399. http://dx.doi.org/10.1016/j.emj.2009.11.002

Dutra, M. G. L., \& Saito, R. (2002). Conselhos de Administração: análise de sua composição em um conjunto de companhias abertas brasileiras. Revista de Administração Contemporânea, 6(2), 09-27. http://dx.doi.org/10.1590/S1415-65552002000200003

Fama, E. F., \& Jensen, M. C. (1983). Separation of ownership and control. Journal of Law of and Economics, 26(2), 301-325. http://dx.doi.org/10.1086/467037

Fraga, J. B., \& Silva, V. A. B. (2012). Board diversity and firm performance: an empirical investigation in the Brazilian market. Brazilian Business Review, 1, 55-77. http://dx.doi.org/10.15728/bbrconf.2012.3

Gomes, J. A., Souza Neto, J. A., \& Martins, H. C. O. (2006). Conselho de Administração em Empresas Familiares: Avaliação da Adesão ao Código de Melhores Práticas do Instituto Brasileiro de Governança Corporativa. Anais do Encontro Anual da Associação Nacional de Pós-Graduação e Pesquisa em Administração. Salvador, Bahia, Brasil, 30 .

Guerra, S. (2010). Os papéis do Conselho de Administração nas empresas listadas no Brasil. IBGC em Foco Publicação Trimestral do Instituto Brasileiro de Governança Corporativa. n. 49, 17-20.

Hermalin, B., \& Weisbach, M. (1991). The effect of board composition and direct incentives on firm performance. Financial Management, 21(4), 101-112. http://dx.doi.org/10.2307/3665716

Jensen, M., \& Meckling, W. (1976). Theory of the firm: managerial behavior, agency costs and ownership structure. Journal of Financial Economics, 3(4), 305-360. http://dx.doi.org/10.1016/0304-405X(76)90026-X

Linck, J. S., Netter, J. M., \& Yang, T. (2008). The determinants of board structure. Journal of Financial Economics, 87(2), 308-328. http://dx.doi.org/10.1016/j.jfineco.2007.03.004

Martins, H. C., \& Rodrigues, S. B. (2005). Atributos e Papéis dos Conselhos de Administração das Empresas Brasileiras. Revista de Administração de Empresas, 45(special $23-35$. http://dx.doi.org/10.1590/S0034-75902005000500002

Organization for Economic Co-operation and Development. (2015). Principles of Corporate Governance. OECD Publishing, Paris. 2015.

Pace, E. S. U., Basso, L. F. C., \& Silva, M. A. (2003). Indicadores de Desempenho como Direcionadores e Valor. Revista de Administração Contemporânea, 7(1), 37-65. http://dx.doi.org/10.1590/S1415-65552003000100003

Pereira, A. G., Bruni, A. L., Rocha, J. D., Lima Filho, R. N., \& Faria, J. A. D. (2010). Teoria dos contratos, governança corporativa e auditoria: delineamentos para a discussão em teoria da contabilidade. Anais do Simpósio de Excelência em Gestão e Tecnologia, Resende, Rio de Janeiro, Brasil, 7.

Petrobras. (2016). Participação do Setor de Petróleo e Gás chega a 13\% do Pib Brasileiro. Retrieved on Feb. 2 , 2016 from:http://www.petrobras.com/pt/magazine/post/participacao-do-setor-de-petroleo-e-gas-chega-a-13-do-pib-brasil eiro.htm

Raheja, C. G. (2005). Determinants of board size and composition: A theory of corporate boards. Journal of Financial and Quantitative Analysis, 40(2), 283-306. http://dx.doi.org/10.1017/S0022109000002313

Ribeiro, M. N. (2007). Aspectos Jurídicos da Governança Corporativa. São Paulo: Quartier Latin.

Rosenstein, S., \& Wyatt, J. G. (1990). Outside directors, board independence and shareholder wealth. Journal of Financial Economics, 26, 175-191. http://dx.doi.org/10.1016/0304-405X(90)90002-H

Schwartz-Ziv, M., \& Weisbach, M. S. (2012). What do boards really do? Evidence from minutes of board meetings. Journal of Financial Economics, 108, 349-366. http://dx.doi.org/10.1016/j.jfineco.2012.04.011

Shimakura, S. E. (2006). Interpretação do Coeficiente de Relação. Retrieved on Mar. 12 , 2016 from: http://leg.ufpr.br/ silvia/CE003/node74.html

Shleifer, A., \& Vishny, R. (1997). A survey of corporate governance. Journal of Finance, 52(2), $737-783$. http://dx.doi.org/10.1111/j.1540-6261.1997.tb04820.x

Silveira, A. M., Barros, L. A. B. C., \& Famá, R. (2003). Estrutura de Governança e Valor Das Companhias Abertas 
Brasileiras. Revista de Administração de Empresas, 43(3), 50-64.

http://dx.doi.org/10.1590/S0034-75902003000300005

Stacey, J., \& Stacey, A. (2014). Perceptions of the impact of board members' individual perspectives on the social and environmental performance of companies. The Journal of the Southern African Institute of Mining and Metallurgy, $114,957-968$.

Weisbach, M. S. (1988). Outside directors and CEO turnover. Journal of financial Economics, 20, 431-460. http://dx.doi.org/10.1016/0304-405X(88)90053-0

\section{Copyrights}

Copyright for this article is retained by the author(s), with first publication rights granted to the journal.

This is an open-access article distributed under the terms and conditions of the Creative Commons Attribution license (http://creativecommons.org/licenses/by/3.0/). 